Original Paper http://ajol.info/index.php/ijbes $\quad$ http://indexmedicus.afro.who.int

\title{
Physico-chemical characteristics of water sample from Aiba Stream in Iwo, Nigeria and its distillate from a Double Slope Solar water distillation unit
}

\author{
Adesoji Alani OLANREWAJU ${ }^{1 *}$ and Joshua Ademola OYEWOLE ${ }^{2}$ \\ ${ }^{1}$ Department of Chemistry and Industrial Chemistry, Bowen University, Iwo, Osun State, Nigeria. \\ ${ }^{2}$ Departments of Physics and Solar Energy, Bowen University, Iwo, Osun State, Nigeria. \\ Corresponding author; E-mail: sojylanrey2009@yahoo.com ; sojylanrey2009@gmail.com;
}

Tel: $+2348038078074 ;+2347033229088$

\begin{abstract}
This study aimed at assessing the effectiveness of solar distillation in purification of water. The water sample collected from Aiba stream was subjected to double slope solar water distillation unit. The physicochemical characteristics of the raw sample and the distillate were determined using standard methods. The results showed that there were variations between raw sample and the distillate. The $\mathrm{pH}$, temperature and conductivity mean values for raw water and distillate were $9.20 \pm 1.10 ; 30.70 \pm 0.71 ; 240 \pm 14.14$ and $8.10 \pm$ $1.06 ; 25.1 \pm 0.57 ; 110.00 \pm 14.14 \mathrm{mg} / \mathrm{L}$, respectively. The $\mathrm{SO}_{4}{ }^{2-}, \mathrm{PO}_{4}{ }^{3-}, \mathrm{Cl}^{-}, \mathrm{NO}_{3}{ }^{-}$mean values for raw water sample and distillate fell in the range $33.10-53.40 \pm 0.57-1.27$ and $17.20-28.40 \pm 0.14-0.85 \mathrm{mg} / \mathrm{L}$, respectively. The TDS, TSS, BOD, COD mean values of raw water sample and the distillate were $68.70 \pm 0.42$; $50.10 \pm 0.42 ; 8.20 \pm 0.57 ; 52.20 \pm 0.85 \mathrm{mg} / \mathrm{L}$ and $52.10 \pm 0.57 ; 42.20 \pm 0.57 ; 5.30 \pm 0.57 ; 37.40 \pm 0.71 \mathrm{mg} / \mathrm{L}$, respectively. The mean values for the distillate were lower compared to raw sample. Hence, double slope solar water distillation unit might be a very good mechanism for producing portable water.
\end{abstract}

(C) 2016 International Formulae Group. All rights reserved.

Keywords: Portable water, mean values, standard methods, purification, variations, mechanism.

\section{INTRODUCTION}

Water is an essential natural resource for sustaining life and environment and has always been thought to be available in abundance and a free gift of nature (Dikio, 2010). It is used in various ways for domestic, industrial and agricultural purposes. As important as it is to life, it is one of the most poorly managed resources in the world (Fakayode, 2005). The provision of portable water to the rural and urban population is necessary to prevent health hazards (Lemo, 2002). Natural water contains some types of impurities whose nature and amount vary with source of water.

One of the most critical crises in developing countries is the lack of adequate portable water. The supply of drinking water has become one of the major concerns of the population and the availability of good quality water is an indispensable feature for preventing diseases and improving quality of life (Oluduro and Aderiye, 2007; Djossou et al., 2015).

However, poor water quality remain a 
major health threat (Akindele and Olutona, 2014). The usual source of drinking water is from streams, rivers, wells and boreholes which are usually not treated. Unfortunately, clean, pure and safe water only exists briefly in nature and is immediately polluted by prevailing environmental factors and anthropogenic activities largely caused by the poor and uncultured living habit of people as well as the unhealthy practices of factories, industries and agricultural practices, resulting in the discharge of effluents and untreated wastes into streams, rivers and underground water (Kaizer et al., 2001; Obasi and Balogun, 2001; Ovrawah and Hymore, 2001; Dan et al., 2013; Hisseien et al., 2015). The water meant for drinking and domestic purposes must meet laid down local and international standards, hence the consumer stand the risk of water borne diseases (Nwankwoala and Nwagbogwu, 2012). Water from most sources is therefore unfit for immediate consumption without some sort of treatment. Ideally, the quality of waters should be assessed by the use of physical, chemical and biological parameters in order to provide a broad spectrum of information for appropriate water management (Akindele et al., 2015). A good knowledge of the chemical qualities of raw water is necessary so as to guide its suitability for use. Thus, regular physicochemical analysis of water at source must be carried out to determine or check the effectiveness of treatment process.

Various means and methods had been employed in water treatment in order to make it good and portable. Apart from simple distillation process, solar distillation is quite an old technology that can be dated back to over five centuries. It came to use as far back as 1551 by Arab alchemists. Over the years many solar plants and individual stills have nevertheless, the acute shortage of a good and clean portable water is still a major problem particularly in the rural areas of the developing countries like Nigeria; this make the efforts to improve on this old technology inevitable. Therefore, this work presents the physico-chemical characteristics of raw water sample of Aiba stream in Iwo and the distillate gotten from it using a double slope solar distillation unit.

\section{MATERIALS AND METHODS Description of study area}

The study was conducted along the Aiba stream in the ancient town of Iwo. Aiba stream was an outlet of Aiba reservoir (Figure 1). The stream drains through Kuti road, Oweyo and Oke-Afo before empties itself into Oba river. The location considered in this study is Oweyo. This area lies between latitude $07^{\circ} 37^{\prime} 41.0^{\prime \prime} \mathrm{N}$ and longitude $04^{\circ} 11^{\prime} 0.75^{\prime \prime} \mathrm{E}$ with elevation of $226 \mathrm{~m}$. This area is along the major road leading to Bowen University, a faith-based private institution. Notable activities within this vicinity are filling station, car wash services, irrigation practices and motor park (Atobatele and Olutona, 2013).

\section{Sample collection}

The water sample was collected using pre-treated 5 Litres water plastic container. Prior to this, the sample container was soaked in $10 \%$ Nitric acid for 48 hours after which it was rinsed with water and distill water respectively. The water sample container was also rinsed thrice with the stream water before collection. To maintain the physical properties of the water and to inhibit the growth of bacteria, the water sample was stored in refrigerator prior determination. The distillate was also collected after the raw water sample was subjected to the double solar distillation unit constructed. 


\section{Determination of physico-chemical parameters}

The $\mathrm{pH}$, water temperature and conductivity were determined in situ. The $\mathrm{pH}$ was determined using digital $\mathrm{pH}$ meter (Eutech Instrument, Malaysia), while conductivity and water temperature were determined using EC Testr 2 dual range conductivity meter.

Total suspended solid (TSS), total dissolved solid (TDS) and total solids (TS) were determined using gravimetric methods as described in APHA (1998). Chemical oxygen demand (COD), Total organic Matter (TOM) and Total hardness (TH) were also determined using APHA (1998). Chloride, phosphate and nitrate were determined using argentometric titration, colorimetric technique and screen ultraviolet methods, respectively. Modifies Winkler's method was used to determine the Biological Oxygen Demand (BOD) and sulphate was determined using turbidimetric method (Ademoroti, 1996).

\section{RESULTS AND DISCUSSION}

The results of physico-chemical parameters for both raw water sample and the distillate are presented in Table 1.

\section{Physical parameters \\ Temperature}

Water temperature is important for its effects on the chemical and biochemical reactions in organisms (Jayalakshmi et al., 2011). The temperature values for the raw sample and the distillate were $30.70 \pm 0.71$ and $25.01 \pm 0.57{ }^{\circ} \mathrm{C}$, respectively (Table 1).

The water sample temperature was found to be higher than the $25{ }^{\circ} \mathrm{C}$ recommended for drinking water by WHO (2006); while that of the distillate falls within the range. The higher temperature of the raw sample could be attributed to the time and season of collection (peak of dry season).
The reduced temperature of the distillate was probably due to the cooling processes the sample had undergone during the solar distillation and this has also removed the settling solids that the water contain since temperature of water affects the efficiency of treatment units and low temperature increases the viscosity, which in turn diminishes the efficiency of settling the solids that the water may contain because of the resistance that the high viscosity offers to the downward motion of the particles as they settle (Jayalakshmi et al., 2011).

pH

$\mathrm{pH}$ is a measure of acidity and alkalinity of a solution and it is calculated as the negative logarithm of hydrogen ion concentration (Jayalaskhmi et al., 2011). pH is one of the most important operational water quality parameters. The $\mathrm{pH}$ value for raw water and distillate were $9.20 \pm 1.10$ and $8.10 \pm 1.06$, respectively (Table 1). This result shows that both values were alkaline but raw water was more alkaline than the distillate water, which might be attributed to the presence of ions in the raw water sample. This observation confirm the previous studies on physicochemistry of Aiba stream by Atobatele and Olutona (2013) who reported that $\mathrm{pH}$ value of Aiba stream was slightly alkaline. The distillate $\mathrm{pH}$ value falls within the WHO recommended value for drinking water compared to the raw water sample $\mathrm{pH}$ which was above the recommended value. The alkaline nature of these samples might due to presence of solid wastes and ions such as calcium and magnesium (David, 2004). Atmospheric deposition resulting from heavy traffic flow along this sample location might also be a contributory factor to the suspended matter in the water body.

\section{Conductivity}

The electrical conductivity (EC) of a water body is very vital in determining the water quality. It is directly related to the concentrations of ionized substance in the water and a measurement of water's current. Also, levels affected by 
the electrical conductivity of water are a direct function of its total dissolved solids, organic matters and temperature (Jayalakshmi et al., 2011). Conductivity value for raw and distillate water were $240.00 \pm 14.14$ and $110.00 \pm 14.14 \mu \mathrm{S} / \mathrm{cm}$, respectively (Table 1). This study revealed that the electrical conductivity value in raw water was twice that of the distillate. This could be attributed to the fact that most of the suspended matter have been removed as a result of solar distillation. Conductivity values for both the raw water sample and the distillate were lower than recommended standard of $1000 \mu \mathrm{S} / \mathrm{cm}$ for drinking water by WHO (2011) and Nigerian Standard for Drinking Water Quality.

\section{Chemical parameters Sulphate}

Sulphate is a stable, highly oxidized, soluble form of sulphur, which is generally present in natural surface and ground waters (Jayalakshmi et al., 2011). When water is overloaded with organic waste to the point that oxygen is removed, sulphate being an electron acceptor is often used for breakdown of organic matter to produce hydrogen sulphide $\left(\mathrm{H}_{2} \mathrm{~S}\right)$, which gives a rotten egg smell. The presence of sulphate in drinking water can cause noticeable taste, and very high levels might cause a laxative affecting unaccustomed consumers (WHO, 2011). The Sulphate mean values for the raw water sample and the distillate were $33.10 \pm 1.27$ and $28.40 \pm 0.85 \mathrm{mg} / \mathrm{L}$ respectively.

This result showed that sulphate value for raw sample was higher than that of the distillate. Though, the two values were below the recommended value of 250 $\mathrm{mg} / \mathrm{L}$ by WHO (2011). This higher value for the raw water sample might due to contamination of the stream with sulphate containing waste being dumped into it, since the sample location is very close to car wash, houses, filling station etc. and it has been established that sulphate levels even in natural water can increase due to industrial contamination with sulphuric acid, bisulphate and aluminium sulphate used in water purification plants (Jayalakshmi et al., 2011).

\section{Phosphate}

Phosphate and nitrate estimation are important in evaluating the potential biological productivity of surface water (Vankatesharaju et al., 2010). Anthropogenically, phosphate comes from industrial wastes, fertilizers, pesticides, and cleaning compounds. Natural sources of phosphate include phosphate containing rocks and solid or liquid wastes (Jayalakshmi et al., 2011). The phosphate values of both raw sample and the distillate were $53.4 \pm 0.85$ and $20.70 \pm 0.42 \mathrm{mg} / \mathrm{L}$ respectively (Table 1). Therefore, the phosphate value of the distillate is lower than that of the raw water sample, though, the value does not falls within the recommended WHO value of $2.2 \mathrm{mg} / \mathrm{L}$. This lower value of the distillate could be attributed to the removal of some of these wastes as impurities in the raw sample by the solar distillation processes.

Nitrate

The most highly oxidized form of nitrogen in the nitrogen cycle, which includes activities in the atmosphere, hydrosphere and biosphere is nitrate (Edema et al., 2001). High concentration of nitrate in drinking water may cause methemoglobinemia in small children (Olutona et al., 2012) and therefore, its concentration in public water supplies should be monitored correctly. This study reveals that the nitrate value for the distillate is lower $(17.20 \pm 0.57 \mathrm{mg} / \mathrm{L})$ than that of the raw sample $(37.60 \pm 0.85 \mathrm{mg} / \mathrm{L})$, though both were below the recommended WHO standards of 50 $\mathrm{mg} / \mathrm{L}$.

\section{Chloride}

Chlorides are generally present in natural water in widely varying concentrations. Excessive chloride in potable water is not particularly harmful and the criteria 
set for this anion are based primarily on palatability and its potentially high corrosiveness (Bhujangaiah and Nayak, 2005). This could be attributed to dissolution of salts deposits, domestic and industrial sewage discharge of effluent etc. The results of the mean value of the raw sample and the distillate were presented in Table 1 and Figure 1. The raw water sample value was $43.30 \pm 0.57 \mathrm{mg} / \mathrm{L}$ while that of the distillate was $28.10 \pm 0.14 \mathrm{mg} / \mathrm{L}$. Though, high chloride content gives a salty taste to water, but these values were below the recommended WHO standard of 250 $\mathrm{mg} / \mathrm{L}$.

\section{Biochemical Oxygen Demand (BOD)}

Increasing organic matter results in the excess oxidation of organic matter to carbon (iv) oxide and the water creates an atmosphere of oxygen depletion leading to higher BOD levels (Jayalakshmi et al., 2011). Increase in BOD can be due to heavy discharge of industrial waste water effluent, animal and crop waste and domestic sewage. The BOD value of raw sample was higher $(8.20 \pm 0.57 \mathrm{mg} / \mathrm{L})$ than that of the distillate $(5.30 \pm 0.57 \mathrm{mg} / \mathrm{L})$ which was very close to the WHO recommended value of $6.0 \mathrm{mg} / \mathrm{L}$. It is important to note that low BOD content is an indication of good quality water while a high BOD indicates a polluted water. BOD directly affects the amount of dissolved oxygen (DO) in rivers and streams. The greater the BOD, the more rapidly oxygen is depleted in the water. Higher content of organic load as well as the high proliferation of micro-organisms might be the causative factors for maximum BOD levels in the raw sample (Shukla et al., 1989).

\section{Chemical Oxygen Demand (COD)}

COD is a measure of the amount of oxygen required for complete oxidation of carbon content of organic matter present in a sample of water, waste water or effluent by a strong chemical oxidant to produce $\mathrm{CO}_{2}$ and water (Kumar and Bahadur, 2009). It is a fact that all organic compounds with a few exceptions can be oxidizing agents under the acidic condition. COD test is used to measure the load of organic pollutants in ordinary water sample or industrial waste water. It is also useful in pinpointing toxic condition and presence of biological resistance substances. Both the COD and BOD values are a measure of the relative oxygen-depletion effect of a water sample and waste contaminant (Jayalakshmi et al., 2011). In Table 1, Our study revealed that the distillate has a lower COD value $(37.40 \pm 0.71 \mathrm{mg} / \mathrm{L})$ compared to the raw sample value $(52.20 \pm 0.85 \mathrm{mg} / \mathrm{L})$.

Total Suspended Solids (TSS)

Total Suspended Solids (TSS) play an important role in water and waste water treatment. Suspended solid do not mean that they are floating matters and remain on top of water layer. They are under suspension and in water sample (Kavitha et al., 2012). The presence of suspended solid in water sample causes depletion of oxygen level (Kavitha et al., 2012). The determination of TSS in both the raw sample and the distillate show that the mean value of the raw water sample and the distillate were $50.10 \pm 0.42 \mathrm{mg} / \mathrm{L}$ and $42.20 \pm$ $0.57 \mathrm{mg} / \mathrm{L}$ respectively (Table 1 ). These two values were below the recommended WHO standard value of $500 \mathrm{mg} / \mathrm{L}$.

\section{Total Dissolved Solids (TDS)}

The total solid concentration in raw water sample represents the colloidal form and dissolved species (Gupta and Kumari, 2015). The values for the TDS determination of raw water sample and the distillate are shown in Table 1 and Figure 1. The raw water sample value was $68.70 \pm 0.42 \mathrm{mg} / \mathrm{L}$ while that of the distillate was $52.10 \pm 0.57 \mathrm{mg} / \mathrm{L}$. The lower value of the distillate compared to that of the raw sample might be attributed to reduction or removal of dissolved particles and impurities by the solar distillation processes. Though, the two values were below the recommended 
WHO standard value of $600 \mathrm{mg} / \mathrm{L}$.

\section{Total Hardness (TH)}

Total hardness is the hardness of the mineral content of water that is irreversible by boiling. The total hardness can be equivalent to the total calcium and magnesium hardness. High hardness can result in abnormal cloudiness and heat insulating scales in the boilers reducing their efficiency (Kumar and Bahadur, 2009). However, levels of hardness that are too low could make the water corrosive and more aggressive (corrosionpedia). It is also a measure of capacity of water to precipitates the soap. Soap is precipitated mainly by calcium and magnesium present in polyvalent cation and they are in complex forms frequently with organic constituents (Jayalakshmi et al., 2011).
Similarly, in most fresh water, total hardness is imparted mainly by calcium and magnesium ions, which apart from sulphate, chloride and nitrate are found in combination with carbonates and bicarbonates (Sangpal et al., 2011). The mean $\mathrm{TH}$ values for the raw sample and the distillate were $580.00 \pm 14.14$ and $248.10 \pm 1.27 \mathrm{mg} / \mathrm{L}$ respectively (Table 1). The high value of raw water sample confirmed the hardness of the water due to the presence of the mineral ions $\left(\mathrm{Ca}^{2+}\right.$ and $\left.\mathrm{Mg}^{2+}\right)$ in it from the source while the lower mean value of the distillate $(248.10 \pm 1.27 \mathrm{mg} / \mathrm{L})$ which was almost half the recommended WHO standard value of $500 \mathrm{mg} / \mathrm{L}$ might substantiate the removal of these ions by the solar distillation set-up.

Table 1: Physicochemical parameters of the raw sample and the distillate.

\begin{tabular}{lccccc}
\hline Physico-chemical & \multicolumn{2}{c}{ Raw sample } & \multicolumn{2}{c}{ Distillate } & WHO \\
\cline { 2 - 5 } parameters & Min - max & Mean/SD & Min max & Mean/SD & limits \\
\hline $\mathrm{pH}$ & $8.42-9.98$ & $9.20 \pm 1.10$ & $7.35-8.85$ & $8.10 \pm 1.06$ & $6.5-8.5$ \\
Temperature $\left({ }^{\circ} \mathrm{C}\right)$ & $30.20-31.20$ & $30.70 \pm 0.71$ & $24.70-25.50$ & $25.10 \pm 0.57$ & $<25.0$ \\
Conductivity $(\mu \mathrm{S} / \mathrm{cm})$ & $230-250.00$ & $240.00 \pm 14.14$ & $100-120.00$ & $110.00 \pm 14.14$ & 1000 \\
$\mathrm{SO}_{4}{ }^{2-}(\mathrm{mg} / \mathrm{L})$ & $32.20-34.00$ & $33.10 \pm 1.27$ & $27.80-29.00$ & $28.40 \pm 0.85$ & 250 \\
$\mathrm{PO}_{4}{ }^{3-}(\mathrm{mg} / \mathrm{L})$ & $52.80-54.00$ & $53.40 \pm 0.85$ & $20.40-21.00$ & $20.70 \pm 0.42$ & 2.20 \\
$\mathrm{NO}_{3}{ }^{-}(\mathrm{mg} / \mathrm{L})$ & $37.00-38.20$ & $37.60 \pm 0.85$ & $16.80-17.60$ & $17.20 \pm 0.57$ & 50 \\
$\mathrm{Cl}^{-}(\mathrm{mg} / \mathrm{L})$ & $42.90-43.70$ & $43.30 \pm 0.57$ & $28.00-28.20$ & $28.10 \pm 0.14$ & 250 \\
$\mathrm{BOD}(\mathrm{mg} / \mathrm{L})$ & $7.80-8.60$ & $8.20 \pm 0.57$ & $4.90-5.70$ & $5.30 \pm 0.57$ & 6.0 \\
$\mathrm{COD}(\mathrm{mg} / \mathrm{L})$ & $51.60-52.80$ & $52.20 \pm 0.85$ & $36.90-37.90$ & $37.40 \pm 0.71$ & \\
$\mathrm{TSS}(\mathrm{mg} / \mathrm{L})$ & $49.80-50.40$ & $50.10 \pm 0.42$ & $41.80-42.60$ & $42.20 \pm 0.57$ & 500 \\
$\mathrm{TS}(\mathrm{mg} / \mathrm{L})$ & $41.80-42.40$ & $42.10 \pm 0.42$ & $32.90-33.70$ & $33.30 \pm 0.57$ & 500 \\
$\mathrm{TDS}(\mathrm{mg} / \mathrm{L})$ & $68.40-69.00$ & $68.70 \pm 0.42$ & $51.70-52.50$ & $52.10 \pm 0.57$ & 600 \\
$\mathrm{TOM}(\mathrm{mg} / \mathrm{L})$ & $1.04-1.70$ & $1.37 \pm 0.47$ & $0.08-0.12$ & $0.10 \pm 0.03$ & \\
$\mathrm{TH}(\mathrm{mg} / \mathrm{L})$ & $570-590.00$ & $580.00 \pm 14.14$ & $247.20-249.00$ & $248.10 \pm 1.27$ & 500 \\
\hline
\end{tabular}

SD: Standard Deviation; Min: Minimum values; Max: Maximum values; $\quad$ WHO: World Health Organization; mg/L: milligram per litre; $\mu \mathrm{S} / \mathrm{cm}$ : micro Siemens per centimeter. 


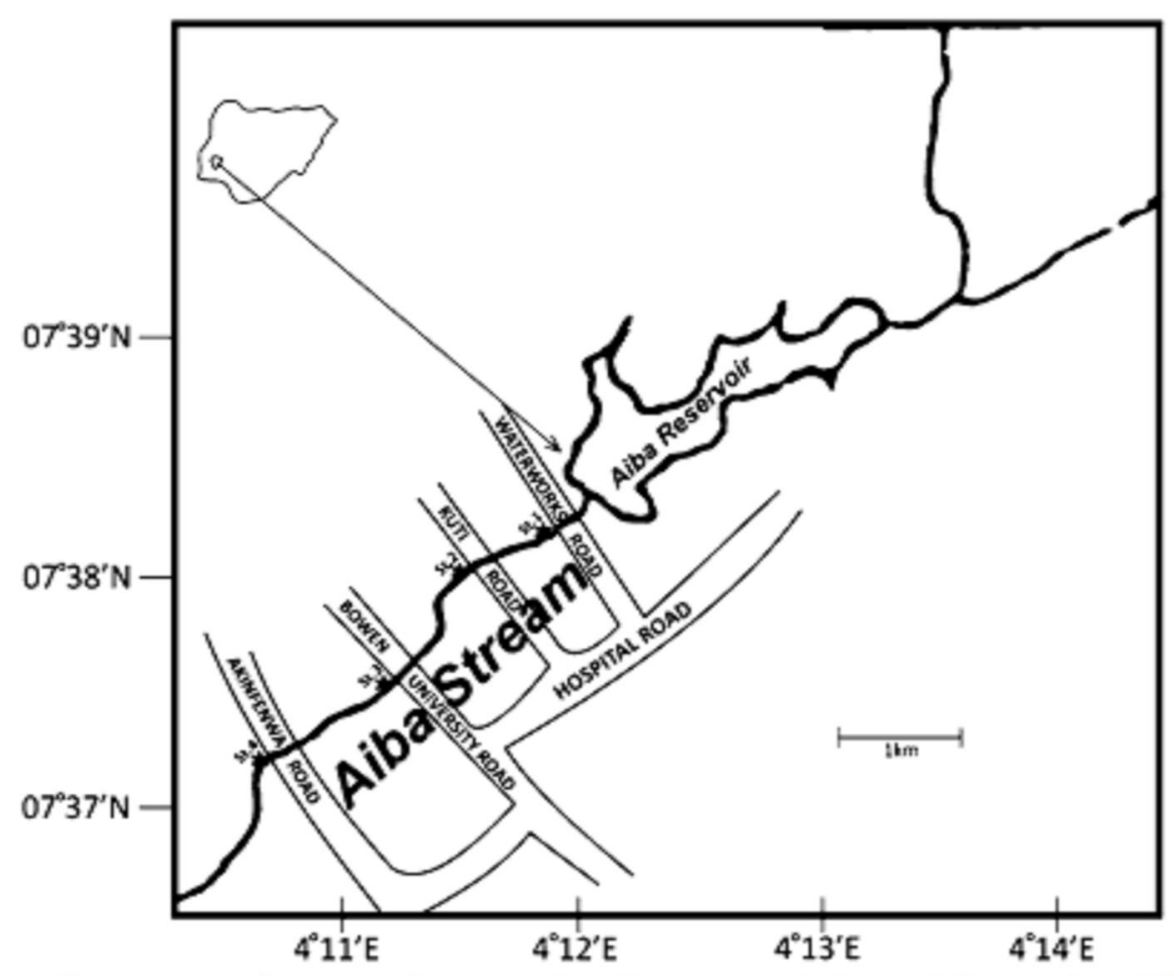

Figure 1: Map of Aiba stream, Iwo, Osun state, Nigeria (adapted from Akindele and Liadi, 2014).

\section{Conclusion}

The study has shown that Aiba stream is poor in terms of physico-chemical water quality as a result of anthropogenic activities. It also revealed the effectiveness of solar distillation in purification of water and as a useful means of producing portable water. The results showed that most of the parameters analyzed for the distillate had the mean values that fall within the permissible WHO standards for drinking water, while some were very close and some were below. Those mean values that were out of range of WHO recommended limit for the distillate were still better compared to the raw water sample values. Therefore, these findings suggest that the double slope solar distillation unit would be a useful means of providing portable water for rural and urban areas.

\section{COMPETING INTERESTS}

The authors declare that there are no competing interests.

\section{AUTHORS' CONTRIBUTIONS}

AA O supervised the bench work and the analysis of the samples, interpretation of the results, preparation of the manuscript and revising critically the technical and intellectual content of the manuscript. JAO designed the study, led the collection of sample, constructed the double slope solar water distillation unit and supplied the distillate. Both authors read and approved the final manuscript.

\section{ACKNOWLEDGMENTS}

The authors acknowledged the efforts of Mr. Emmanuel Adewuni Akintunde and Dr. Godwin Oladele Olutona of Chemistry and Industrial Chemistry Department, Bowen University, Iwo, Nigeria. 


\section{REFERENCES}

Ademoroti CMA. 1996. Standard Method for Water and Effluent Analysis. March Prints and Consultancy, Foludex press: Ibadan; 182.

APHA 1998. Standard Methods for the Examination of Water and Waste Water. American Public Health Association: Washington.

Akindele EO, Adedapo TA, Olawoye OO, Olutona GO, Adu BW. 2015. Preliminary limnological survey of Ori stream, Iwo, Osun State, Nigeria. Int. J. Biol. Chem. Sci., 9(1): 329-341. DOI : http://dx.doi.org/10.4314l/ijbcs.v9i1.29

Akindele EO, Liadi AA. 2014. Diversity and response of benthic macro invertebrates to natural and induced environmental stresses in Aiba stream Iwo, Southwestern Nigeria, West Afr. J. Pure Appl Ecol., 22: 101-111.

Atobatele EO, Olutona GO. 2013. Spatioseasonal physico-chemistry of Aiba Stream, Iwo, Nigeria. Afr. J. Biotech., 12(14): 1630-1635. DOI : 10.5897/AJB12.2608

Bhujangaiah NS, Nayak PV. 2005. Study of ground water quality in and around Shimoga city, Karmataka. J. Ind. Coun. Chem., 22(1): 42-47.

Dan UI, Ekpo FE, Etim DE. 2013. Influence of heavy metals pollution in borehole water collected within abandoned battery industry, Essien Udim, Nigeria. $J$. Environ. Sci. Water Resour., 2(1): 22-26.

David C. 2004. Small Water Supplies. Cromwell Press, Trowbridge, Wiltshire. India; 234-268.

Dikio ED. 2010. Water quality evaluation of Vaal River, Sharpeville and Bedworth lakes in the Vaal Region of South Africa. Res. J. Appl. Sci. Eng. Tech., 2(6): 574579.
Djossou D, Adechina A, Kelome N, Houinato D, Pilipili CM. 2015. Analysis of the chemical quality of underground waters in the municipality of Dassa-zoume. Int. J. Biol. Chem. Sci., 9(5): 2735-2742. DOI : http://dx.doi.org/10.43141/ijbcs.v9i5.42

Edema MO, Omemu AM, Fapetu OM. 2001. Microbiology and Physicochemical Analysis of different sources of drinking water in Abeokuta. Nigeria. Niger. J. Microbiol., 15(1): 57-61.

Fakayode SO. 2005. Impact Assessment of Industrial Effluent on Water Quality of the Receiving Alaro River in Ibadan, Nigeria. Ajeam-Ragee, 10: 1-13.

Gupta YK, Kumari B. 2015. Physico-chemical characteristics of underground water quality of some villages of Jhunjhunu district of Rajasthan, India. Int. J. Res. Chem. Environ., 5(4): 95-102.

Hisseien AT, Kamga R, Mahamat TN. 2015. Physico-chemical analysis of Logone river water at Moundou city in Southern Chad. Int. J. Biol. Chem. Sci., 9(3): 16541664. DOI http://dx.doi.org/10.43141/ijbcs.v9i3.44

Jayalakshmi V, Lakshmi N, SigaraCharya MA. 2011. Assessment of physicochemical parameters of water and waste waters in and around Vijayawada. Int. J. Res. Pharm. Biomed. Sci., 2(3): 1040-1046.

Kaizer AN, Adaikpoh EO, Osakwe SA, Obanogun-Odiete E. 2001. Heavy Metal Pollution of Surface Water within Coal Mining Sites around Enugu, SouthEastern Nigeria. Agid 1-5.

Kavitha RV, Murthy KV, Makam R, Asith KA. 2012. Physico-chemical analysis of effluents from pharmaceutical industry and its efficiency study. Int. J. Eng. Res. Appl., 2(2): 103-110. 
Kumar A, Bahadur Y. 2009. Physicochemical studies on the pollution potential of river Kosi at Rampur, India. $W . J$. Agric. Sci., 5(1): 1-4.

Lemo OO. 2002. Bacteriology determination of water with long term storage. BSc. thesis, University of Agriculture, Abeokuta, p. 40.

Nwankwoala HO, Nwagbogwu CN. 2012. Characteristics and quality assessment of ground water in parts of Akure, SouthWestern Nigeria. J. Environ. Sci. Water Res., 1(4): 67-73.

Obasi RA, Balogun O. 2001. Water Quality and Environmental Impact Assessment of Water Resources in Nigeria. Afr. J. Envr. St., 2(2): 228-231.

Oluduro AO, Adewoye BI. 2007. Efficiency of moringa oleifera seed extract on the microflora of surface and ground water. J. Plant Sci., 6: 453-438.

Olutona GO, Aribisala OG, Akintunde EA. 2012. A study of chemical speciation of metals in aquatic bottom sediment of Aiba reservoir, Iwo, Nigeria. Afr. J. Environ. Sci. Tech., 6(8): 312-321. DOI : 10.5897/AJEST11.227
Ovrawah L, Hymore FK. 2001. Quality of Water from Hand-Dug Wells in Warri Environs of Niger Delta Region. Afr. J. Envr. St., 2(2): 169173.

Sangpal RR, Kulkarni UD, Nandurkar YM. 2011. An assessment of the physico-chemical properties to study the pollution potential of Ujjani reservoir, Solapur District, India. ARPN. J. Agric. Biol. Sci., 6(3): 3438.

Shukla SC, Kant R, Tripathi BD. 1989. Ecological investigation on physiochemical characteristics and phytoplankton productivity of river Ganga at Varanasi. Geobios., 16: 2027.

Venkatesharaju K, Ravikumar P, Somaskekar RK, Prakash KL.2010. Physico-chemical and bacteriological investigation on the river Cauvery of Kollegal stretch in Karnataka, Kathmandu University. J. Sci. Eng. Tech., 6(1): 50-59.

WHO (World Health Organization). 2011. Guidelines for drinking water quality (4th Edn). WHO Press; 56. 